\title{
Kinerja Teknologi Budidaya Jagung Hibrida di Indonesia
}

\author{
TRI HASTINI*) DAN IRMA NOVIANA \\ Balai Pengkajian Teknologi Pertanian Jawa Barat, Jl. Kayuambon No. 80 \\ Lembang Bandung Barat 40391 \\ ${ }^{*}$ E-mail: trihastini@gmail.com
}

\begin{abstract}
The performance of hybrid maize cultivation technology in Indonesia. Maize is the most important crop after rice. Beside as a food, maize has other functions as forage and raw material of bioethanol. In Indonesia, the need of maize increases every year. To fulfil the need, an appropriate breakthrough that can increase maize production significantly, is required. The most popular breakthrough is the use of hybrid variety, that is the first generation derived from two or more pure lines crossing. This review discusses the results of hybrid maize researchs and assessments at various types of agroecosystem. Maize hybrid variety planting accompanied by the appropriate location specific technologies could increase maize productivity significantly.
\end{abstract}

Keywords: hybrid maize, technologies, specific location

\section{PENDAHULUAN}

Jagung merupakan tanaman pangan

penting kedua setelah padi bagi masyarakat Indonesia. Selain masih dimanfaatkan sebagai makanan pokok di beberapa wilayah, jagung merupakan komponen utama dalam ransum pakan ternak, serta sebagai bahan baku bioetanol. Saat ini mulai berkembang manfaat jagung sebagai pangan fungsional karena jagung mengandung serat pangan yang diperlukan oleh tubuh manusia. Menurut Suarni \& Yasin (2011), jagung mempunyai nilai Indeks Glikemik (IG) yang lebih rendah daripada beras, yaitu antara 50 - 90 sehingga lebih aman untuk dikonsumi oleh penderita diabetes. Warna biji jagung yang beragam menunjukkan bahwa jagung kaya senyawa pigmen yang dikandungnya, sehingga bisa dijadikan media untuk biofortifikasi. Selain sebagai pangan, peran jagung sebagai pakan ternak juga sangat penting karena mengandung energi yang tinggi. Kandungan pati jagung yang tinggi (72-73\%) (Suarni \& Widowati, 2007), menjadikan jagung dapat dimanfaatkan sebagai bioetanol dengan 
TRI HASTINI DAN IRMA NOVIANA. Kinerja Teknologi Budidaya Jagung Hibrida di Indonesia

melalui proses fermentasi. Bioetanol tersebut dapat dimanfaatkan pada industri minuman, farmasi, kosmetik, dan bahan bakar. Bahkan janggel jagung juga dapat dimanfaatkan sebagai pakan ternak sapi. Hasil pengkajian memberikan informasi bahwa penggunaan satu bagian janggel jagung yang dicampur empat bagian dedak dapat memberikan penambahan berat badan sapi sebesar $0,354 \mathrm{~kg} / \mathrm{ekor} / \mathrm{hari}$, sedangkan pada perlakuan kontrol penambahan berat badan sapi sebesar $0,219 \mathrm{~kg} / \mathrm{ekor} / \mathrm{hari}$. Nilai RC rasio yang diperoleh adalah 1.08 (Rohaeni et al., 2008).

Kebutuhan jagung di Indonesia senantiasa meningkat dari tahun ke tahun, mengikuti perkembangan industri peternakan. Kebutuhan tersebut dipenuhi dari produksi domestik maupun impor. Pemenuhan dari produksi domestik cenderung menurun dari tahun 2009 sampai dengan tahun 2013 yaitu sebesar 98\% menjadi 89\% (Kusuma \& Rachbini, 2019). Hasil kajian Suryana \& Agustian (2014) menginformasikan bahwa usahatani jagung di Indonesia mempunyai $\mathrm{RC}$ ratio 1,73 sehingga cukup menguntungkan. Keuntungan finansial yang dapat diperoleh sebesar 6,7 juta/ha, dan keuntungan ekonomi sebesar 8,7 juta/ha dengan RC rasio 1,90.
Permintaan jagung untuk memenuhi kebutuhan pangan dan pakan harus diusahakan pemenuhannya melalui intensifikasi pertanian. Salah satu terobosan penting untuk peningkatan produksi jagung adalah penggunaan varietas hibrida yang mempunyai potensi hasil tinggi. Hasil kajian di tiga desa di Kecamatan Palolo Kabupaten Sigi Sulawesi Tengah pada tingkat petani, usahatani jagung hibrida lebih menguntungkan dibandingkan non hibrida karena secara nyata memberikan tingkat pendapatan yang lebih tinggi, dengan RC rasio usahatani jagung hibrida dan non hibrida berturut-turut sebesar 1,74 dan 1,27 (Antara 2010). Tabri (2010) melaporkan bahwa pada perlakuan pemupukan yang sama, bobot 100 biji (g) dan hasil biji (ton/ha) jagung hibrida lebih tinggi dibandingkan jagung komposit sebesar 3,04 - 4,36\% pada bobot 100 biji dan 6,76$14,90 \%$ pada hasil biji.

Berdasarkan analisis data BPS (2018), rata-rata produksi jagung Indonesia dari tahun 2011 sampai dengan tahun 2015 sebesar 18,83 juta ton, dengan produktivitas rata- rata 4,89 ton/ha. Angka tersebut tidak membedakan sumber produksi dari jagung hibrida ataupun jagung komposit bersari bebas. Pemasok terbesar produksi jagung adalah provinsi Jawa Timur, diikuti oleh 
Jawa Tengah dan Lampung karena pada tahun 1908. Shull melakukan selfing mempunyai areal pertanaman yang lebih pada tanaman jagung dan menemukan bahwa luas, meskipun dari segi produktivitas jagung-jagung hasil selfing sangat lebih unggul provinsi Jawa Barat (7,09 menurun vigornya. Namun pada akhirnya ton/ha).

\section{Varietas Jagung Hibrida}

Hibrida mempunyai pengertian keturunan pertama dari suatu perkawinan. Dalam pemuliaan tanaman, istilah hibrida dilambangkan dengan $F_{1}$ (Filial 1) dari persilangan dua tetua (Nagur et al., 1991). Dengan demikian, jagung hibrida adalah jagung yang benihnya merupakan biji $F_{1}$ hasil persilangan dua tetua. Tetua jagung hibrida merupakan galur murni yang dihasilkan dari proses penyerbukan sendiri secara terus-menerus dengan bantuan manusia atau dikenal dengan istilah selfing. Selfing tersebut dilakukan secara turun temurun paling tidak sampai enam generasi. Setelah melewati proses pengujian-pengujian maka terpilihlah dua galur murni yang akan dijadikan sebagai tetua. Faktor yang dipertimbangkan dalam pemilihan tetua jagung hibrida adalah efek heterosis (vigor hibrida), yang menyebabkan keturunan pertama akan lebih superior dibanding dengan tetuanya.

Jagung hibrida pertama kali di perkenalkan oleh George Harrison Shull
Shull menemukan bahwa jika dua jagung hasil selfing disilangkan, maka akan menghasilkan keturunan yang jauh lebih vigor daripada kedua tetuanya. Pada tempat yang terpisah, EM East juga melakukan percobaan yang sama, hanya saja East belum sempat menemukan fenomena heterosis, hingga pada akhirnya setelah membaca laporan Shull, East setuju dengan penemuan Shull (Crow, 1998).

Fenomena heterosis merupakan hal yang paling mendasar dalam pemuliaan jagung hibrida (Stuber, 1976). Heterosis atau hybrid vigor merupakan suatu fenomena penampilan tanaman F1 yang lebih superior dibandingkan kedua tetuanya, dan fenomena tersebut diduga karena heterozigositas (Shull, 1910). Lamkey \& Edward (1999) mengemukakan bahwa fenomena heterosis terjadi karena adanya aksi gen dominan atau over dominan saat susunan genetik heterozigot. Frascaroli et al. (2007) dari hasil penelitiannya menemukan bahwa fenomena heterosis tidak hanya disebabkan oleh alel pada lokus tunggal, tetapi juga oleh QTL (Quantitative Traits Loci). Lebih lanjut dinyatakan, 
TRI HASTINI DAN IRMA NOVIANA. Kinerja Teknologi Budidaya Jagung Hibrida di Indonesia

heterosis disebabkan oleh interaksi alelik jagung hibrida antara lain PT BISI (dominansi dengan berbagai level), International Tbk, PT Dupon Indonesia, PT sedangkan interaksi non alelik (epistasis) Monsanto Indonesia, PT East West Seed kurang memainkan peran. Indonesia, PT DuPont Pioneer Indonesia, Jagung hibrida di Indonesia dan PT Syngenta Indonesia dihasilkan oleh para pemulia pemerintah, (https://belajartani.com diakses 27 swasta, dan perguruan tinggi. Pemuliaan November 2019). Varietas yang dihasilkan jagung hibrida oleh pemerintah oleh perusahaan swasta disajikan pada Tabel dilaksanakan oleh Balai Penelitian Tanaman 2. Sedangkan pemuliaan oleh perguruan Serealia, Badan Penelitian dan tinggi antara lain oleh Institut Pertanian Pengembangan Pertanian, Kementerian Bogor (IPB) yang pada tahun 1985 Pertanian. Berdasarkan deskripsi varietas melepaskan varietas IPB 4.

jagung Badan Penelitian dan Pengembangan Pertanian telah menghasilkan 39 varietas jagung hibrida hingga tahun 2016 (Aqil et al., 2012; Aqil \& Arvan, 2016). Pada tahun-tahun berikutnya dihasilkan dua varietas jagung hibrida berdasarkan laporan kinerja Balai Penelitian Tanaman Serealia 2018 (Balai Penelitian Tanaman Serealia, 2019). Nama-nama varietas jagung hibrida yang dihasilkan oleh Badan Penelitian dan Pengembangan Pertanian disajikan pada Tabel 1. Perusahaan swasta yang bergerak dalam pemuliaan Varietas jagung hibrida yang dihasilkan Badan Penelitian dan Pengembangan Pertanian umumnya diperbanyak oleh perusahaan swasta berdasarkan lisensi. Pada tahun 2018, terdapat 8 perusahaan swasta yang memperoleh lisensi untuk mengembangkan benih jagung hibrida NASA 29, dan 14 perusahaan yang mengembangkan jagung hibrida Bima 20 URI, dengan masa lisensi lima tahun (Balai Penelitian Tanaman Serealia, 2019). 
Tabel 1. Varietas jagung hibrida yang dihasilkan oleh Badan Penelitian dan Pengembangan Pertanian sampai dengan tahun 2016

\begin{tabular}{lll}
\hline Nama varietas & Nama varietas & Nama varietas \\
\hline Semar-1 & Bima-5 & Bima-19 URI \\
Semar-2 & Bima-6 & Bima-20 URI \\
Semar-3 & Bima-7 & Bima-Putih-1 \\
Semar-4 & Bima-8 & Bima-Putih-2 \\
Semar-5 & Bima-9 & HJ 21 Agritan \\
Semar-6 & Bima-10 & HJ 22 Agritan \\
Semar-7 & Bima-11 & Pulut URI 3 H \\
Semar-8 & Bima-12Q & JH 27 \\
Semar-9 & Bima-13Q & JH 234 \\
Semar-10 & Bima-14 Batara & Nakula Sadewa (NASA) 29 \\
Bima-1 & Bima-15 Sayang & Jhana-1 \\
Bima-2 Bantimurung & Bima-16 & Provit A1 \\
Bima-3 Bantimurung & Bima-17 & Provit A2 \\
Bima-4 & Bima-18 & \\
\hline
\end{tabular}

Sumber : Deskripsi Varietas Unggul Jagung 2016 dan Laporan Kinerja Balai Penelitian Tanaman Serealia 2018

Tabel 2. Varietas jagung hibrida yang dihasilkan oleh perusahaan swasta sampai dengan tahun 2016

\begin{tabular}{ll}
\hline \multicolumn{1}{c}{ Nama varietas } & \multicolumn{1}{c}{ Perusahaan } \\
\hline C-1 sd C-10 & PT Monagro Kimia \\
Pioneer-1 sd Pioneer 23 & PT Pioneer Hibrida Indonesia \\
BISI-1 sd BISI 18 & PT BISI International Tbk \\
SHS-2, SHS-11, SHS-12 & PT Sang Hyang Sri \\
Jaya-1 dan Jaya 2 & PT Asian Hybrid Seed Technologies \\
NKRI & PT Asian Hybrid Seed Technologies, Inc \\
N35 & PT Citra Nusantara Mandiri \\
NK 11, NK 22, NK 33, NK 55, NK 66, & PT Syngenta Indonesia \\
NK 81, NK 82, NK 88, NK 99 & \\
DK-2 dan DK-3 & PT Monagro Kimia (Monsanto Indonesia) \\
R-01 & PT Redi Mulya Abadi \\
P 28, P 29, P31 & PT DuPont Indonesia \\
JK 7, JK 8 & PT Asiana Bio Grow \\
PAC 224, PAC 759 & PT Advanta Seed Indonesia \\
\hline
\end{tabular}

Berdasarkan Direktorat Jenderal benih jagung hibrida, yaitu jagung yang Tanaman Pangan (2018) terdapat istilah benihnya merupakan keturunan pertama 
TRI HASTINI DAN IRMA NOVIANA. Kinerja Teknologi Budidaya Jagung Hibrida di Indonesia

dari persilangan dua galur atau lebih yang

sifat individunya heterozigot dan homogen.

Selanjutnya benih jagung hibrida umum adalah benih jagung yang dihasilkan oleh perusahaan nasional atau multinasional, dan benih jagung hibrida badan litbang adalah benih jagung hibrida hasil penelitian Badan Penelitian dan Pengembangan Pertanian.

Pengelolaan Tanaman Terpadu (PTT) Jagung

Standar budidaya jagung hibrida yang dikeluarkan oleh Badan Penelitian dan Pengembangan Pertanian adalah melalui pendekatan pengelolaan tanaman terpadu (PTT). Penentuan teknologi dalam pendekatan PTT bersifat dinamis disesuaikan dengan variasi lingkungan tumbuh tanaman, sosial ekonomi dan budaya petani. Komponen teknologi yang digunakan dalam PTT jagung adalah penggunaan varietas unggul berdaya hasil tinggi dan stabil, benih berkualitas, penyiapan lahan dan pengendalian gulma, optimalisasi populasi tanaman, rasionalisasi penggunaan pupuk, pembuatan alur irigasi, pengelolaan hama dan penyakit secara terpadu, serta pasca panen dengan alat (Bakhri, 2007). Dalam implementasinya di lapangan, pelaksanaan teknis budidaya tersebut berkembang, sehingga menghasilkan teknologi yang bervariasi dan spesifik lokasi.

Erawati \& Hipi (2010) melaporkan bahwa di provinsi Nusa Tenggara Barat (NTB), umumnya jagung dibudidayakan petani pada lahan kering di musim hujan dan di lahan sawah pada musim kemarau. Pengkajian budidaya jagung hibrida pada lahan sawah dengan jenis tanah Inseptisol yang mempunyai kandungan $\mathrm{P}$ dan $\mathrm{K}$ tinggi, menggunakan varietas Bima-2, Bima-3, Bima-4, Bisi 16, dan NT 10 menunjukkan bahwa varietas Bima-4 memberikan hasil tertinggi sebesar 10,68 ton/ha pada panen pertama. Produktivitas terendah terlihat pada varietas Bima-2 sebesar 8,14 ton/ha. Pada panen kedua, produktivitas tertinggi 
dicapai oleh Bima-3 sebesar 7,05 ton/ha, sub-optimal, toleran kekeringan, atau toleran sedangkan produktivitas Bima-4 turun kemasaman.

menjadi 6,71 ton/ha. Meskipun mengalami penurunan produktivitas, namun masih lebih tinggi dibandingkan varietas yang lain. Penurunan produktivitas tersebut disebabkan oleh kurangnya ketersediaan air irigasi pada fase pembungaan dan pengisian tongkol. Sutoro (2015) menyatakan bahwa produktivitas jagung ditentukan oleh kualitas lingkungan tumbuh dan varietas yang ditanam. Kualitas lingkungan tumbuh antara lain kesuburan tanah, ketersediaan air, dan musim tanam. Kesuburan tanah yang baik, air tersedia cukup pada musim tanam yang sesuai akan meningkatkan peluang terpenuhinya kebutuhan utama tanaman untuk tumbuh dan berkembang. Pemilihan varietas harus memperhatikan karaktertistik spesifiknya yang disesuaikan dengan lahan yang akan ditanami untuk mendapatkan hasil yang optimal. Saat ini telah tersedia varietas yang beradaptasi baik dengan lahan
Varietas Bima-3 terlihat lebih unggul dibandingkan Bima-2 dan Bima-4 meskipun dalam deskripsi morfologi mempunyai jumlah baris/tongkol, diameter tongkol yang sama, bobot 1000 biji lebih rendah daripada Bima-2. Keunggulan varietas Bima-3 dibanding Bima-2 dan Bima-4 yaitu ketahanannya terhadap penyakit bulai. Varietas Bima-2 agak tahan, sedangkan varietas Bima-4 peka terhadap penyakit bulai. Hal ini membuktikan bahwa sifat ketahanan suatu varietas terhadap hama atau penyakit dapat berkontribusi terhadap hasil yang tinggi. Tanaman yang terserang penyakit bulai akan mengalami hambatan dalam fotosintesis (Hoerossalam et al., 2013). Penurunan hasil akibat serangan penyakit bulai dapat mencapai $100 \%$ pada tanaman yang peka, terutama jika serangan tersebut terjadi pada umur jagung $10-15$ hari setelah tanam (Talanca, 2013). Pakki 
TRI HASTINI DAN IRMA NOVIANA. Kinerja Teknologi Budidaya Jagung Hibrida di Indonesia (2017) melaporkan bahwa Bima-3 Perbedaan ketiga karakter tersebut Bantimurung mempunyai ketahanan penyakit menghasilkan perbedaan struktur kanopi dan bulai yang tinggi yang ditunjukkan dari selanjutnya mengakibatkan perbedaan dalam intensitas penyakit yang rendah dengan hubungan antara fraksi radiasi aktif jumlah konidia yang tinggi. Diduga kondisi fotosintetis yang diintersep (fIPAR) oleh tersebut yang menyebabkan Bima-3 kanopi dan indeks luas daun hijau (GLAI). Bantimurung umumnya mempunyai hasil Madonni \& Otegui (1996) menyatakan yang lebih tinggi dari Bima-2 dan Bima-4. bahwa rasio fIPAR/GLAI tidak dapat Varietas Bima-3 Bantimurung terbukti digunakan untuk menduga fotosintesis lebih unggul dan layak untuk dikembangkan kanopi tanaman, produksi biomasa, efisiensi berdasarkan penelitian di Kabupaten Pangkep penggunaan radiasi, dan pembentukan biji dan Barru, Sulawesi Selatan. Penggunaan pada jenis jagung hibrida tertentu dan pada teknologi jarak tanam $75 \mathrm{~cm}$ x $20 \mathrm{~cm}$ maupun fase pertumbuhan tertentu. Dengan demikian, legowo $100 \mathrm{~cm}$ x $50 \mathrm{~cm}$ x $20 \mathrm{~cm}$ yang kendali genetik sangat menentukan keduanya menghasilkan kepadatan populasi kemampuan metabolisme suatu varietas 66.666 tanaman per hektar menghasilkan jagung hibrida. produktivitas yang tidak berbeda yaitu 11 Pengujian calon varietas hibrida 12 ton/ha (Syuryawati \& Faesal, 2016). NASA-29 di lahan sawah tadah hujan di Madonni \& Otegui (1996) melaporkan Lamongan, Provinsi Jawa Timur bahwa tiga jenis jagung hibrida yang menunjukkan keunggulan-keunggulan calon dijadikan perlakuan dalam percobaan varietas tersebut dibanding yang lain. menunjukkan perbedaan total jumlah daun, NASA-29 mempunyai karakteristik tongkol luas setiap daun, dan sudut daun. yang besar dan panjang dengan diameter 
janggel yang kecil, sehingga memberikan hasil yang lebih tinggi (Bachtiar et al., 2018). Hasil pengkajian kinerja budidaya jagung hibrida di lahan sawah di Jawa Barat dilaporkan oleh Haryati \& Karsidi (2014). Pengkajian menggunakan lima varietas jagung hibrida yaitu Bima-3, Bima4, Bima-5, Bima-6, dan Bima 19. Teknologi yang diterapkan sesuai dengan komponen PTT jagung, yaitu penggunaan varietas unggul, pemberian pupuk organik 2 ton/ha, dosis pupuk anorganik berdasarkan hasil perangkat uji tanah sawah (PUTS), dan pengendalian hama dan penyakit berdasarkan konsep Pengelolaan Hama Terpadu (PHT). Pada pengkajian ini, aplikasi pemupukan menggunakan Urea, SP36 dan $\mathrm{KCl}$ dengan dosis masing-masing 350, 175 dan $50 \mathrm{~kg} / \mathrm{ha}$ yang mana Urea diberikan tiga kali, yaitu pertama pada umur 7- 10 hari setelah tanam (hst), kedua pada umur 28-30 hst, dan ketiga pada umur 40-45 hst. SP36 dan $\mathrm{KCl}$ diberikan seluruhnya pada pemupukan pertama. Hasil pengkajian memberikan informasi bahwa varietas Bima-4 mempunyai produktivitas terbaik dibandingkan empat varietas yang lain sebesar 8,74 ton/ha. Tingginya produktivitas varietas Bima-4 diduga disebabkan oleh diameter tongkol yang nyata lebih besar, tongkol yang nyata lebih panjang, sehingga menghasilkan jumlah biji per baris yang nyata lebih banyak, meskipun jumlah baris per tongkol tidak berbeda nyata dengan varietas yang lain.

Percobaan budidaya jagung pada lahan kering di Kabupaten Seram, Maluku dilaporkan oleh Sirappa \& Nurdin (2010). Percobaan menggunakan varietas jagung hibrida Bima-3 Bantimurung, Bisi-2 dan varietas komposit Srikandi Kuning-1. Pada percobaan ini digunakan jarak tanam $75 \mathrm{~cm}$ $\times 40 \mathrm{~cm}$ dengan dua biji per lubang tanam. Pupuk anorganik yang digunakan berupa Urea $300 \mathrm{~kg} / \mathrm{ha}$, SP36 $200 \mathrm{~kg} / \mathrm{ha}$, dan 50 kg/ha KCl. Pupuk Urea diberikan tiga kali yaitu pada pemupukan pertama (7 hst) 
TRI HASTINI DAN IRMA NOVIANA. Kinerja Teknologi Budidaya Jagung Hibrida di Indonesia

sebesar $100 \mathrm{~kg} / \mathrm{ha}$, pemupukan kedua (30 hst) sebesar $150 \mathrm{~kg} / \mathrm{ha}$, dan pemupukan ketiga 45 hst sebesar $50 \mathrm{~kg} / \mathrm{ha}$. SP36 dan $\mathrm{KCl}$ diberikan seluruhnya pada pemupukan pertama. Pupuk kandang ayam sebesar 2 ton/ha diberikan sebagai pupuk organik. Hasil percobaan memberikan informasi bahwa varietas Bima3 Bantimurung mempunyai tongkol terpanjang, lingkar tongkol terbesar, bobot tongkol dengan dan tanpa kelobot tertinggi, bobot 1000 biji, bobot biji per tongkol, bobot biji per petak serta produktivitas tertinggi (8.71 ton/ha) dibandingkan varietas Bisi-2 dan Srikandi Kuning-1. Dengan demikian varietas Bima-3 Bantimurung secara agronomis sesuai untuk dikembangkan di wilayah Maluku.

Efendi et al. (2013) melaporkan bahwa pola panjang daun pada varietas Bima-3 berbeda dengan varietas Bisi 16 dan NK 99. Daun yang berada di bawah tongkol (daun 1 -8) pada Bima-3 lebih pendek $(50-85 \mathrm{~cm})$, namun daun diatas tongkol (daun $9-14$ ) lebih panjang $(85-42 \mathrm{~cm})$ dibandingkan daun varietas Bisi $16(83-37 \mathrm{~cm})$ dan NK 99 (81 - $38 \mathrm{~cm})$. Lebar daun di bawah tongkol (daun $1-8$ ) tidak berbeda nyata antara ketiga varietas, sedangkan lebar daun di atas tongkol (daun 9 -14) pada Bima 3 menunjukkan ukuran yang lebih lebar (6 - 10 cm). Lebar daun varietas Bisi 16 dan NK 99 berturut-turut $4-8 \mathrm{~cm}$ dan $5-9 \mathrm{~cm}$. Daun ke-7 dan ke-8 pada varietas NK 99 (212 $610 \mathrm{~cm}^{2}$ ), lebih luas dibanding Bima 3 (195 $\left.571 \mathrm{~cm}^{2}\right)$ dan Bisi $16\left(182-484 \mathrm{~cm}^{2}\right)$. Varietas Bima 3 mempunyai sudut daun $\left(38^{\circ}\right)$, lebih besar dibandingkan Bisi $16\left(27^{\circ}\right)$ dan NK $99\left(22^{\circ}\right)$. Besarnya sudut daun berkorelasi positif dengan ukuran sudut daun dengan nilai $r=0,81$. Semakin kecil sudut daun, semakin toleran terhadap peningkatan kepadatan populasi, sehingga varietas Bima 3 kurang toleran untuk ditanam dengan jarak tanam yang rapat. Bima 3 mempunyai potensi biomas tanaman segar yang lebih besar (21,7 ton/ha) daripada Bisi 16 (16,6 
ton/ha) dan NK 99 (17,5 ton/ha). Potensi tersebut diperoleh dari diameter batang yang lebih besar $(21.2 \mathrm{~mm})$, sedangkan diameter batang Bisi 16 dan NK 99 berturut-turut 20,6 mm dan 17,7 mm. Rendemen biji Bima 3 lebih kecil (74\%) dibanding Bisi 16 dan NK $99(77,3 \%-79,9 \%)$. Rendahnya rendemen varietas Bima 3 karena bobot janggel lebih besar sedangkan bobot 100 butir lebih rendah. Bobot janggel varietas Bima 3 (76,9 g) lebih besar dibanding bobot janggel Bisi 16 dan NK 99 berkisar 54,9 g - 69, 3 g. Pada karakter bobot 100 biji, Bima 3 lebih rendah (39,8 g), sedangkan bobot 100 biji Bisi 16 dan NK 99 berada pada kisaran 43,6 g-47,1 g.

Biba (2016) melaporkan bahwa budidaya jagung di sentra produksi jagung di Kabupaten Takalar, Sulawesi Selatan menggunakan varietas hibrida menggunakan jarak tanam $75 \mathrm{~cm} \times 20 \mathrm{~cm}$, dengan satu biji per lubang tanam. Pada petani yang menanam varietas Bima-3, aplikasi produktivitasnya 7,9 ton/ha. pemupukan menggunakan Urea, SP36 dan
NPK Phonska masing-masing 200 kg, 100 $\mathrm{kg}$, dan $150 \mathrm{~kg} / \mathrm{ha}$, dan pemupukan dilakukan dua kali. Pemupukan pertama pada umur 1015 hst dengan pemberian seluruh dosis SP36 dan NPK Phonska, serta $150 \mathrm{~kg} / \mathrm{ha}$ Urea, sedangkan pemupukan kedua dilakukan pada umur $30-35$ hst menggunakan Urea $50 \mathrm{~kg} / \mathrm{ha}$. Pada petani yang menanam varietas N-35 dan Bisi-2, pemupukan dilakukan dua kali yaitu pada umur 18 - 20 hst, dan $40-45$ hst. Jenis pupuk yang diberikan pada pemupukan pertama yaitu Urea $150 \mathrm{~kg} / \mathrm{ha}$ dan SP36 50 $\mathrm{kg} / \mathrm{ha}$, sedangkan pada pemupukan kedua hanya Urea dengan dosis $50 \mathrm{~kg} / \mathrm{ha}$. Dengan adanya perbedaan teknologi budidaya tersebut, maka produktivitas yang diperoleh pun menunjukkan perbedaan. Varietas Bima3 menunjukkan produktivitas yang lebih tinggi, yaitu rata-rata 9,5 ton/ha, sedangkan pada varietas $\mathrm{N}-35$ dan Bisi-2, rata-rata 


\section{TRI HASTINI DAN IRMA NOVIANA. Kinerja Teknologi Budidaya Jagung Hibrida di Indonesia}

Menurut Marschner (1986), dosis pupuk kandang yang tinggi (3 ton/ha) konsentrasi rata-rata unsur hara $\mathrm{N}, \mathrm{P}$, dan $\mathrm{K}$ pada tanah liat berdebu akan menghasilkan untuk pertumbuhan tanaman yang memadai indeks luas daun (ILD) tertinggi yaitu 6,18. berturut-turut adalah 15.000, 10.000, dan ILD merupakan parameter yang mengukur $2.000 \mathrm{mg} / \mathrm{kg}$ bahan kering. Unsur $\mathrm{K}$ potensi tanaman dalam berfotosintesis mempunyai peran penting dalam sehingga secara langsung berpengaruh pertumbuhan tanaman, yaitu menjaga terhadap pertumbuhan dan perkembangan tekanan turgor sel sehingga sel dapat tanaman. ILD diukur berdasarkan rasio total berkembang dengan baik, berperan dalam luas daun dengan luas yang ditutupi. Menurut proses membuka dan menutupnya stomata, Wahyudin et al. (2015), nilai ILD 6,18 dan berperan penting dalam mengaktifkan tersebut sedikit lebih tinggi daripada nilai lebih dari 60 jenis enzim. K juga berperan kisaran indeks luas daun yang optimal untuk dalam transport asimilat dan mengatur laju tanaman budidaya yaitu $3-5$ (dikutip dari fotosintesis yang bermuara dalam Gardner dan Pierce, 1991). Lykhovyd et al. mendukung hasil biji. Namun demikian pada (2019) melaporkan ILD pada jagung manis spesies tanaman yang sama terdapat variasi besarnya peran $\mathrm{K}$, tergantung dari interaksi ion $\mathrm{K}^{+}$dengan ion-ion yang lain (Dibb \& Thompson, 1985).

Informasi dari hasil penelitian Wahyudin et al. (2015) menyatakan bahwa pada jarak tanam yang lebar $(80 \mathrm{~cm}$ x $20 \mathrm{~cm})$, populasi 62.500 tanaman per hektar, dengan dengan populasi 80.000 tanaman per hektar sebesar 3,72. Sementara itu, Tabri (2013) menyatakan bahwa ILD sebesar 6,19 ditunjukkan oleh jagung hibrida Bisi 2 yang ditanam dengan populasi 71.428 tanaman per hektar pada jarak tanam legowo $(100 \mathrm{~cm} \times$ $40 \mathrm{~cm}) \times 20 \mathrm{~cm}$, lebih besar dari nilai ILD yang dilaporkan oleh Wahyudin et al. (2015). 
Yartiwi et al. (2019) menyatakan bahwa kecil luas daun, maka semakin kecil kecukupan sinar matahari mendukung intersepsi cahaya matahari.

terhadap peningkatan produktivitas tanaman, $\begin{array}{llll}\text { Varietas } & \text { Pioner } & 12 & (\mathrm{P}-12)\end{array}$ sebagaimana hasil percobaan bahwa jagung menunjukkan respon yang positif nyata yang ditanam dengan jarak tanam legowo terhadap pupuk SP 36-WIKA Agro pada menunjukkan hasil yang nyata lebih tinggi karakter tinggi tanaman dan hasil jagung. dibandingkan dengan jarak tanam tegel pada Hasil jagung maksimum sebesar 5,21 ton/ha varietas Bima-19 URI, Bima-20 URI, dan dicapai pada pemupukan $\mathrm{P}$ dengan dosis Bisi 18. Hal tersebut terjadi karena jarak $66.67 \mathrm{~kg} / \mathrm{ha}$. Sedangkan dosis P optimum tanam yang lebar memberikan ruang adalah $42 \mathrm{~kg} / \mathrm{ha}$ (Kasno, 2009). Patola tumbuh yang leluasa bagi tanaman dan sinar (2008) melaporkan hasil penelitiannya matahari dapat ditangkap tanaman dengan bahwa jarak tanam berpengaruh terhadap baik. Sejalan dengan hasil penelitian panjang tongkol, diameter tongkol, bobot tersebut, Erawati \& Hipi (2017) kering biji pipilan per tongkol, dan bobot menginformasikan bahwa jarak tanam (80 1000 butir pada jagung Pioner 21 (P-21), $\mathrm{cm} \times 50 \mathrm{~cm}) \times 40 \mathrm{~cm}$ dengan sistem double yang mana tongkol terpanjang, diameter row merupakan jarak tanam terbaik karena tongkol terbesar, bobot biji pipilan kering dan menghasilkan produktivitas tertinggi pada bobot 1000 butir tertinggi diperoleh pada varietas jagung Bima-19 dan Bima-20. Puntel jarak tanam $70 \mathrm{~cm} \times 30 \mathrm{~cm}$. Varietas $\mathrm{P}-21$ (2012) menyatakan bahwa intersepsi juga responsif terhadap kombinasi pupuk radiasi matahari dipengaruhi oleh hayati dan jarak tanam pada karakter tinggi penurunan indeks luas daun, terutama tanaman umur 65 hari setelah tanam. penurunan luas daun individu. Semakin Penggunaan pupuk hayati $61 \mathrm{~g}+$ urea $0 \mathrm{~g}$ per 
TRI HASTINI DAN IRMA NOVIANA. Kinerja Teknologi Budidaya Jagung Hibrida di Indonesia

tanaman, dengan jarak tanam $70 \mathrm{~cm} \times 20$

$\mathrm{cm}$ memberikan hasil terbaik pada karakter tinggi tanaman, bobot biji kering, dan bobot 1000 butir (Dani et al., 2014).

\section{Preferensi Petani terhadap Teknologi} Budidaya Jagung Hibrida

Menurut Biba (2016), preferensi atau pilihan petani terhadap suatu varietas ditentukan oleh keunggulan yang dimiliki oleh varietas tertentu. Pada percobaan yang dilaporkan oleh Biba (2016) dan Amin \& Zaenaty (2012), petani memilih suatu varietas karena mempunyai daya tumbuh yang tinggi (> 95\%), harga benih yang murah, ketahanan terhadap penyakit bulai, mempunyai toleransi terhadap kekeringan, mempunyai produktivitas tinggi, dan menghasilkan biomasa yang tetap hijau (stay green) sehingga dapat dimanfaatkan untuk pakan ternak. Biba (2015) juga memberikan informasi bahwa jarak tanam $75 \mathrm{~cm} \times 20 \mathrm{~cm}$ merupakan jarak tanam yang paling disukai petani pada percobaan jarak tanam. Petani menyukai jarak tanam tersebut karena mampu menghasilkan populasi tertinggi yaitu 63.333 tanaman per hektar sehingga diharapkan memberikan hasil tertinggi. Hasil pengkajian menunjukkan bahwa petani menyukai varietas Bima-3 karena mempunyai daya tumbuh yang tinggi, potensi hasil tinggi, toleran terhadap penyakit bulai, bersifat stay green, dan toleran kekeringan (Biba, 2015; Pujiastuti et al., 2013).

\section{Analisis Kelayakan Ekonomi Jagung Hibrida}

Kelayakan usahatani yang layak untuk dikembangkan adalah usahatani yang mampu meningkatkan produktivitas dan pendapatan. Kelayakan tersebut dihitung menggunakan MBCR (Marginal Benefit Cost Ratio) dan jika menghasilkan nilai > 1, dikatakan bahwa teknologi tersebut layak untuk dikembangkan. Dalam analisis sosial ekonomi, Antara (2010) dan Habib (2013) melakukan penelitian seberapa besar pengaruh faktor produksi yang digunakan 
petani terhadap produksi jagung. Antara (2010) mengkaji efisiensi penggunaan input produksi terhadap faktor-faktor yang mempengaruhi produksi jagung hibrida yaitu luas lahan, jumlah benih dan jumlah pupuk. Sebanyak 44 petani dari tiga desa digunakan sebagai responden. Berdasarkan analisis regresi linier berganda, jika luas lahan meningkat $1 \%$, maka produksi jagung hibrida meningkat sebesar $0,3866 \%$, jumlah benih meningkat $1 \%$, maka produksi naik 0,2913\%, dan jika jumlah pupuk mengingkat $1 \%$, maka produksi naik $0,2247 \%$, sedangkan curahan waktu tenaga kerja menunjukkan hasil yang tidak nyata. Berdasarkan hasil penelitian ini, terlihat penggunaan pupuk belum mencapai tingkat optimum dan maksimum, sehingga belum diketahui titik puncak dosis masing-masing jenis pupuk. Jika petani responden menggunakan dosis pupuk dengan takaran berlebih, dengan cara aplikasi yang benar, maka diduga titik balik tersebut akan dapat diketahui. Jika terdapat cukup data, titik balik untuk mencapai batas maksimum $\mathrm{P} \quad(\mathrm{x}, \mathrm{y})$ dapat dihitung menggunakan formula $\left(-b / 2 a,\left(b^{2}-4 a c\right) / 4 a\right)$ pada persamaan kuadratik $y=a x^{2}+b x+c$. Habib (2013) melakukan penelitian dengan metode studi kasus terhadap 30 petani sebagai responden dengan berbagai kelompok umur, pendidikan, jumlah tanggungan, pengalaman usahatani, dan luas lahan yang diusahakan. Pupuk yang digunakan oleh petani adalah NPK dengan dosis yang bervariasi antar petani. Menurut Habib (2013), jika luas lahan meningkat 1\%, maka produksi jagung hibrida meningkat sebesar $0,34 \%$ namun tidak nyata, jika jumlah benih meningkat $1 \%$, maka produksi secara nyata naik $0,15 \%$, jika pupuk meningkat $1 \%$, maka justru terjadi penurunan produksi $0,007 \%$ meskipun tidak nyata, dan peningkatan penggunaan tenaga kerja $1 \%$ akan meningkatkan produksi jagung sebesar $0,5 \%$ namun tidak nyata. Penggunaan pupuk dapat menurunkan 
TRI HASTINI DAN IRMA NOVIANA. Kinerja Teknologi Budidaya Jagung Hibrida di Indonesia

produksi karena digunakan tidak sesuai dengan aturan, baik dosis maupun cara pemberian, dan hal tersebut disebabkan mahalnya harga pupuk. Dosis pupuk yang diberikan umumnya dibawah rekomendasi yang diinformasikan oleh penyuluh setempat, dan cara pemberian pupuk umumnya dengan cara disebar, padahal cara yang direkomendasikan adalah dibenam dalam tanah.

Pada penanaman NASA-29 dengan varietas lain terlihat selisih pendapatan yang diperoleh. Selisih pendapatan yang lebih besar yang diperoleh oleh NASA-29 dibanding varietas lain berkisar 2-3 juta/ha luas lahan. Adopsi calon varietas NASA-29 oleh petani menjadi lebih mudah dengan pembuktian tingginya hasil dan pendapatan tersebut. Hasil analisis $\mathrm{RC}$ rasio dan $\mathrm{BC}$ rasio pada budidaya jagung hibrida NASA-29 berturut-turut sebesar 5,1 dan 4,1 (Bachtiar et al., 2018).

\section{SIMPULAN}

Varietas hibrida merupakan komponen teknologi yang signifikan dalam peningkatan produksi jagung. Varietas hibrida di Indonesia dihasilkan oleh institusi pemerintah maupun perusahaan swasta. Setiap varietas hibrida mempunyai karakter yang spesifik baik secara morfologi maupun fisiologi, sehingga kemampuan untuk menghasilkan biomas juga berbeda. Beragamnya jenis varietas hibrida jagung harus dipadukan dengan komponen teknologi yang spesifik dengan lokasi pengembangan untuk memperoleh produktivitas yang sesuai dengan potensi genetiknya.

\section{DAFTAR PUSTAKA}

Amin, M., S. Zaenaty. (2012). Respon petani terhadap gelar teknologi budidaya jagung hibrida Bima 5 di Kabupaten Donggala. Agrika. 6(1): $34-47$.

Antara, M. (2010). Analisis produksi dan komparatif antara usahatani jagung hibrida dengan non hibrida di Kecamatan Palolo Kabupaten Sigi. J. Agroland. 17(1): 56- 62.

Antara, M. (2010). Efisiensi penggunaan input produksi usahatani jagung hibrida di Kecamatan Palolo 
Kabupaten Sigi. J. Agroland. 17(3): $213-218$.

Aqil, M., R.Y. Arvan. (2016). Deskripsi Varietas Unggul Jagung. Balai Penelitian Tanaman Serealia, Badan Penelitian dan Pengembangan Pertanian.

Aqil, M., C. Rapar, Zubachtirodin. (2012). Deskripsi Varietas Unggul Jagung. Balai Penelitian Tanaman Serealia, Badan Penelitian dan Pengembangan Pertanian. Bahtiar, M. Azrai, M.A. Biba, M. Syakir. 2018. Daya saing calon varietas jagung hibrida NASA29 di Jawa Timur. Penelitian Pertanian Tanaman Pangan. 2(1): 35 $-42$.

Bakhri, S. (2007). Petunjuk Teknis Budidaya Jagung dengan Konsep Pengelolaan Tanaman Terpadu. Badan Penelitian dan Pengembangan Pertanian.

Balai Penelitian Tanaman Serealia. (2019). Laporan Kinerja Balai Penelitian Tanaman Serealia 2018. Badan Penelitian dan Pengembangan Pertanian.

Biba, M.A. (2015). Pengaruh jarak tanam dan varietas jagung hibrida terhadap pendapatan petani. Prosiding Seminar Nasional Serealia. Badan Penelitian dan Pengembangan Pertanian: 745 750.

Biba, M.A. (2016). Preferensi petani terhadap jagung hibrida berdasarkan karakter agronomik, produktivitas, dan keuntungan usahatani. Penelitian Pertanian Tanaman Pangan. 35(1): 81 - 88.

BPS [Badan Pusat Statistik]. (2018). Statistik Indonesia 2018. Badan Pusat Statistik.

Crow, J.F. (1998). 90 Years Ago: The Beginning of Hybrid Maize. edited by Crow JF, Dove WF. Perspectives Anectdotal, historical and critical commentaries on genetics. Genetics 148: 923 - 928 .

Dani, U., M. Asminah, K. Permadi, Y. Karyati, N. Selviyana. (2014). Pengaruh kombinasi formulasi pupuk hayati dan jarak tanam terhadap pertumbuhan dan hasil tanaman jagung (Zea mays L.) kultivar Pioneer 21. Jurnal Ilmu Pertanian dan Peternakan. 2(1): $1-12$.

Dibb, D.W., W.R. Thompson. (1985). Interaction of potassium with other nutrients. In Potassium in Agriculture. Soil Sci. Soc. Amer. Madison. WI. USA. p 515-532. Direktorat Jenderal Tanaman Pangan. 2018. Petunjuk Teknis Pelaksanaan Kegiatan Jagung Tahun 2018. Kementerian Pertanian.

Efendi, R., Z. Bunyamin, A. Andriyani. (2013). Karakter phenotipic jagung hibrida Bima 3. Prosiding Seminar Nasional Serealia 2013. Badan Penelitian dan Pengembangan Pertanian. 2013: 123 - 131.

Erawati, B.T.R., A. Hipi. (2010). Adaptasi beberapa varietas jagung hibrida di lahan sawah. Prosiding Pekan Serealia Nasional 2010. Badan Penelitian dan Pengembangan Pertanian. 2010: 122 131.

Erawati, B.T.R., A. Hipi. (2017). Pengaruh jarak tanam terhadap pertumbuhan dan hasil beberapa varietas jagung hibrida di kawasan pengembangan jagung Kabupaten Sumbawa. Prosiding Seminar Nasional Inovasi Teknologi Pertanian 2016. Balai Besar Pengkajian dan Pengembangan Tekonologi Pertanian. 2016: 608 - 616. Frascaroli, E., M.A. Canè, P. Landi, G. Pea, L. Gianfranceschi, M. Villa, M. Morgante, M.E. Pè. (2007). Classical genetic and quantitative trait loci analysis of heterosis in a mayze hybrid between two elite inbred lines. Genetics. 176: 625 - 644 . 
TRI HASTINI DAN IRMA NOVIANA. Kinerja Teknologi Budidaya Jagung Hibrida di Indonesia

Habib, A. (2013). Analisis faktor-faktor yang mempengaruhi produksi jagung. Agrium. 18(1): 79 - 87.

Haryati, Y., K. Permadi. (2014). Kajian beberapa varietas unggul jagung hibrida dalam mendukung peningkatan produktivitas jagung. Agrotrop 4(2): $188-194$.

Hoerussalam, A. Purwantoro, A. (2013). Induksi ketahanan tanaman jagung (Zea mays L.) terhadap penyakit bulai melalui seed treatment serta pewarisannya pada generasi S1. Ilmu Pertanian. 16(2): 42 - 59.

https://belajartani.com/inilah-daftarperusahaan-benih-di-indonesiaberdasarkan-kepemilikan-

saham/diakses tanggal 27 November 2019 .

Kasno, A., (2009). Respon tanaman jagung terhadap pemupukan fosfor pada typic dystrudepts. J. Tanah Trop. 14(2): 111 $-118$.

Kusuma, P.T.W.W., D.J. Rachbini. (2019). Simulasi kebijakan penambahan areal tanam dan peningkatan produktivitas dalam mendukung tercapainya swasembada jagung. Agritech. 39(3): $188-199$.

Lamkey, K.R., J.W. Edward. (1999). Quantitative genetics of heterosis. hlm 35. dalam The Genetics and Exploitation of Heterosis in Crops. Editor J.G. Coors dan S. Pandey. American Society of Agronomy, Crop Science Society of America, and Soil Science Society of America, Madison.

Lykhovyd, P.V., V.O Ushkarenko, S.O Lavrenko, N.M Lavrenko, O.H Zhuikov, I.M Mrunsky, N.O Didenko. (2019). Leaf area index of sweet corn (Zea mays ssp. saccharata L.) crops depending on cultivation technology in the drip irrigated conditions of the south of Ukraine. Modern Phytomorphology. 13: 1 - 4 .
Madonni, G.A., M.E. Otegui. (1996). Leaf area, light interception, and crop development in maize. Field Crop Research 48: 81 - 87.

Marschner, P., (1986). Marschner's Mineral Nutrition of Hinger Plants $3^{\text {rd }}$ ed. Chennai [IND]. Macmillan Company. p. 5.

Nagur, T., D.L. Oswalt, F. Singh. (1991). A Glossary for Crop Improvement. International Crop Research for the Semi-Arid Tropics. Patancheru Andhra Pradesh India.

Pakki, S., (2017). Kelestarian ketahanan varietas unggul jagung terhadap penyakit bulai Peronosclerospora maydis. Penelitian Pertanian Tanaman Pangan. 1(1): 37 -44.

Patola, E., (2008). Analisis pengaruh pupuk urea dan jarak tanam terhadap produktivitas jagung hibrida P-21 (Zea mays L.). INNOFARM: Jurnal Inovasi Pertanian. 7(1): $51-65$.

Puntel, L.A., (2012). Field characterization of maize photosynthesis response to light and leaf area index under different nitrogen levels: a modelling approach. Graduate Theses and Dissertations. Iowa State University. Ames. Iowa. [USA].

Pujiastuti, E., H. Hanafi, S.W. Budiarti, Suwarti. (2013). Respon petani terhadap beberapa jagung hibrida varietas Bima melalui pendampingan SL-PTT jagung di Kabupaten Gunung Kidul Daerah Istimewa Yogayakarta. Prosiding Seminar Nasional Serealia 2013. Badan Penelitian dan Pengembangan Pertanian 2013: 658 663.

Rohaeni, E.S., N. Amalia, A. Subhan, A. Darmawan, Sumanto. (2008). Pemanfaatan janggel jagung sebagai pakan ternak sapi di Kabupaten Tanah Laut, Kalimantan Selatan. Jurnal 
Pengkajian dan Pengembangan Teknologi Pertanian. 11(2): 126- 132.

Sirappa, M.P., M. Nurdin. (2010). Tanggapan varietas jagung hibrida dan komposit pada pemberian pupuk tunggal $\mathrm{N}, \mathrm{P}, \mathrm{K}$ dan pupuk kandang di lahan kering. Jurnal Agrotropika. 15(2): $49-55$.

Shull, G.H. (1910). The genotypes of maize. The American Naturalist. Vol. XLV: $234-252$.

Stuber, C.W. (1976). Heterosis in plant Breeding. hlm. 227. dalam J. Janick. 1994. Plant Breeding Reviews. vol 12. John Wiley \& Sons, Inc. Toronto.

Suarni, S. \& Widowati. (2007). Struktur, komposisi, dan nutrisi jagung. hlm. 410 - 426. Dalam Badan Penelitian dan Pengembangan Pertanian. Jagung : Teknik Produksi dan Pengembangan. Badan Penelitian dan Pengembangan Pertanian. Suarni, M. Yasin. 2011. Jagung sebagai sumber pangan fungsional. Iptek Tanaman Pangan. 6(1): 41 - 56.

Suryana, A., A. Agustian. (2014). Analisis daya saing usahatani jagung di Indonesia. Analisis Kebijakan Pertanian. 12(2): 143 - 156.

Sutoro. (2015). Determinan agronomis produktivitas jagung. Iptek Tanaman Pangan. 10(1): 39 - 46.

Syuryawati, Faesal. (2016). Kelayakan finansial penerapan teknologi budidaya jagung pada lahan sawah tadah hujan. Penelitian Pertanian Tanaman Pangan. 35(1): 71- 80.

Tabri, F. (2010). Pengaruh pupuk N, P, K terhadap pertumbuhan dan hasil jagung hibrida dan komposit pada tanah inseptisol endoaquepts Kabupaten Barru Sulawesi Selatan. Prosiding Pekan Serealia Nasional 2010. Badan Penelitian dan Pengembangan Pertanian. 2010: 248 - 253.
Tabri, F. (2013). Pengaruh kepadatan populasi terhadap hasil dua varietas jagung hibrida. Prosiding Seminar Nasional Serealia 2013. Badan Penelitian dan Pengembangan Pertanian. 2013: 239 - 243.

Talanca, A.H., (2013). Status penyakit bulai pada tanaman jagung dan pengendaliannya. Prosiding Seminar Nasional Inovasi Teknologi Pertanian 2013. Badan Penelitian dan Pengembangan Pertanian. 2013: 76 -87 .

Wahyudin, A. Ruminta, D.C. Bachtiar. (2015). Pengaruh jarak tanam berbeda pada berbagai dosis pupuk organik terhadap pertumbuhan dan hasil jagung hibrida P-12 di Jatinangor. Jurnal Kultivasi. 14(1): $1-8$.

Yartiwi, Y. Oktavia, A. Damiri, I. Calista. (2019). Pertumbuhan dan hasil beberapa varietas jagung hibrida pada system tanam berbeda di Kabupaten Bengkulu Utara. Prosiding Seminar Nasional Lahan Suboptimal 2018. Unsri Press: 37-42. 